\title{
RANKOS TRAUMĄ PATYRUSIŲ ASMENŲ VEIKLOS PROBLEMŲ IR EMOCINĖS BŪKLĖS STEBE்JIMAS NAMUOSE PO REABILITACIJOS
}

\author{
Milda Gintilienė, Aistė Pranskaitytė-Bielevičienė, Beatričè Dūdaitė \\ Kauno kolegijos Medicinos fakulteto Reabilitacijos katedra
}

Raktažodžiai: ergoterapija, rankos funkcija, rankos anatomija, rankos traumos, reabilitacija.

\begin{abstract}
Santrauka
Rankų traumos visais laikais buvo ir yra labai aktualios. Rankomis atliekami kasdieniai veiksmai, o traumų metu gali būti sužalojamos funkcijai svarbios struktūros, apribojami rankos judesiai, neigiamai veikiantys kasdienę veiklą, sutrikdomi įvairūs žmogaus gyvenimo aspektai [4]. Dažnai patyrę traumą asmenys užsidaro namuose, o toks socialinis pasyvumas labai paveikia asmens gyvenimą, jo galimybes ir padèti visuomeneje bei socialinius santykius [3]. Tyrimo metu buvo siekiama atskleisti rankos traumą patyrusių asmenų veiklos problemas bei emocinę būklę namuose po reabilitacijos. Buvo aiškinamasi, kokių problemų kyla rankos traumą patyrusiam asmeniui kasdienejje veikloje, kaip pasikeitè jo darbinè veikla, koks traumos poveikis laisvalaikio veiklai ir kokie emocinès būklès pokyčiai, patyrus traumą. Duomenų rinkimui buvo taikytas stebėjimas pagal darbo autorių sudarytą stebejjimo protokolą ir pusiau struktūruotas interviu su iš anksto parengtais pagrindiniais atviro tipo klausimais. Tyrime dalyvavo informante, automobilių eismo įvykio metu patyrusi abiejų rankų kaulų dauginius lūžius. Atlikta gautų duomenų turinio analizè, parodžiusi, kad rankos traumą patyrusiems asmenims sunku prisitaikyti prie veiklos problemų, nes jos kelia diskomfortą, trikdo kasdienę veiklą. Daugiausiai problemų kelia apsirengimo, valgymo, savipriežiūros veikla. Rankos trauma sutrikdè informantès darbinę veiklą, nes dèl patirtų sužalojimų ji negalèjo tęsti mokslų ir igyti norimos profesijos ar užsiimti mègstama laisvalaikio veikla. Emocinè būklè keitèsi nuolat, bet tyrimo metu informantè buvo susitaikiusi su situacija ir stengèsi būti kuo labiau nepriklausoma nuo kitų.
\end{abstract}

\section{Ivadas}

Ranka žmogui tarnauja ne tik dirbant, o ir bendraujant su kitais asmenimis [9]. Smegenų pagalba žmogaus rankos gali valdyti aplinką (pvz., atverti duris) ir veikti joje, vykdyti kasdienę, darbinę ar laisvalaikio veiklą. Ranka veikia kaip sensorinis organas, leidžiantis jausti lytejjimą, atlikti kompleksinius judesius be regos pagalbos. Rankos yra labiausiai pažeidžiama kūno vieta. Didžiausia ir pagrindinè plaštakos funkcija yra laikyti ar paimti daiktus, pajausti jų formą bei struktūrą. Žmogaus gyvenime ir jo kasdienèje veikloje traumų pasitaiko labai dažnai, ypač rankų ir plaštakų, nes jomis atliekami kasdieniai veiksmai, keliantys susižalojimo riziką. Dèl traumų gali būti sužalotos svarbios plaštakai ir rankai struktūros [10]. Žmogaus rankos mums tarnauja ịvairiais būdais. Jas sèkmingai naudojame atpažinti objektus ir išsaugoti informaciją apie paviršiaus struktūrą, atitikimą, svorį, formą, dydị, orientaciją, temperatūrą ir kt. Galima parodyti įspūdingą rankų miklumą siekiant, griebiant, manipuliuojant daiktais. Žmogaus rankos tarnauja kaip priemonè kūrybai ịvairiose situacijose, tokiose kaip šokis, skulptūrų darymas, grojimas, piešimas ir kt. [9]. Plaštaka turi sudètingą suemimo struktūrą, susidarančią iš raumenų, sąnarių, fascijų, nervų skaidulų ir kraujagyslių. Dèl šio sudètingumo ranka gali būti labai pažeidžiama. Norint, kad pirštai atliktų veiksmą (suimtų ar sugriebtų daiktą), arčiau esantys sąnariai (riešo ir alkūnès) turi būti stabilūs. Atliekant judesį, jo metu susidaro harmoninga pusiausvyra, atsirandanti tarp atskirų raumenų grupių tonuso. Esant rankai funkcinèje padètyje, susidaro dilbio lenkiamujjų ir tiesiamujų, delno trumpujų raumenų tonuso pusiausvyra. Jei plaštakos sužalojimai gydomi jos neimobilizavus funkcinèje padètyje, tai pertempiami tiesiamieji raumenys, pirštai pasidaro nejudrūs, pritraukiamas nykštys, rankos funkcija sunkiau ir léčiau atsigauna $[1,2]$.

Skeleto ir raumenų trauma dažnai susijusi su lūžiais ar išnirimais, nors galimas ir minkštujų audinių sužalojimas bei ilgalaikès jo pasekmès. Norint suprasti pacientus, patyrusius raumenų ir kaulų traumas, reikia žinoti minkštujjų audinių anatomiją ir suprasti pažeidimo mechanizmą [8]. Dèl lūžimo sutrinka judèjimo-atramos sistemos veikla. Lūžus kaulams, kinta pažeisto segmento ịprastinè funkcinè ir 
anatominė pusiausvyra. Aktyvūs sąnario judesiai tampa ryškiai riboti ar net visai negalimi. Laikinai išnyksta raumenų funkcija, nes po traumos sutrinka judejimo-atramos sistemos biomechanika. Judesių ribojimas būdingas beveik visiems judejjimo-atramos sistemos lūžiams. Ivvykus traumai, sumažeja ne tik aktyvūs, bet ir pasyvūs judesiai [2]. Rankos traumos gali būti pavieniai sužalojimai arba dauginiai lūžiai [6].

Traumą ar lūži patyrusio asmens reabilitacijos metu, svarbu sumažinti skausmą ir uždegimą, siekti judesių amplitudès atkūrimo, funkcinès būklès gerinimo, stiprinimo, propriorecepcijos lavinimo, specifinio aktyvumo ugdymo. Nuo kompleksinio gydymo priklauso, kokie bus reabilitacijos rezultatai. Reabilitacijos procesas yra orientuotas ị tikslą ir trunka ribotą laikotarpị. Reabilitacijos metu pacientui sudaryta namų mankštos programa turi būti vykdoma kiekvieną dieną jam grịžus iš reabilitacijos įstaigos. Kai pacientai išmoksta rankoms skirtus pratimus, tada jiems siūloma tuos pratimus atlikti namuose savarankiškai. Reabilitacijos veiksmingumas priklauso ne tik nuo ergoterapeuto ar kineziterapeuto darbo, bet ir nuo asmens pastangų, noro bei motyvacijos susigrąžinti prarastas ar sutrikusias funkcijas [7].

Tyrimo tikslas - atskleisti rankos traumą patyrusių asmenų veiklos problemas bei emocinę būklę namuose po reabilitacijos.

\section{Tyrimo medžiaga ir metodai}

Tyrimas buvo atliekamas 2021 metų kovobalandžio mènesiais. Informanté - automobilių eismo įvykio metu patyrusi dauginius abiejų rankų kaulų lūžius, 21 metų. Informantẻ buvo apklausta apie atsiradusias veiklos problemas, emocinès būklès pasikeitimą patyrus rankos traumą ir grịžus namo po reabilitacijos. Siekiant atskleisti veiklos problemas ir emocinę būklę po patirtos rankos traumos, pasirinktas kokybinis aprašomasis vertinimo tyrimas, kuriame taikytas pusiau struktūruotas interviu ir klinikinis stebejjimas. Iš anksto buvo parengti pagrindiniai interviu (atviro tipo) klausimai, i kuriuos informante turejo atsakyti. Siekiant gauti kuo daugiau informacijos, pagrindiniai klausimai buvo papildyti šalutiniais (49 papildomi klausimai). Interviu bei stebejjimas buvo vykdomas informantès namuose, jai sutikus, užtikrinant duomenų apsaugą. Pokalbis buvo įrašomas ị diktofoną, perklausomas, transkribuojamas bei perkeliamas ị MS Word dokumentą. Stebèjimas vykdytas pagal darbo autorių sudarytą stebėjimo protokolą, kuriame buvo užrašomi rezultatai. Stebejjimo metu buvo vertinama informantès emocinè būklè viso interviu metu. Duomenų analizei naudota turinio analizè. Šio tyrimo pasirinkta metodika leido išsamiau išanalizuoti gautus duomenis. Prieš tyrimą informantė buvo supažindinta su tyrimo eiga, tikslu ir sutiko dalyvauti apklausoje.

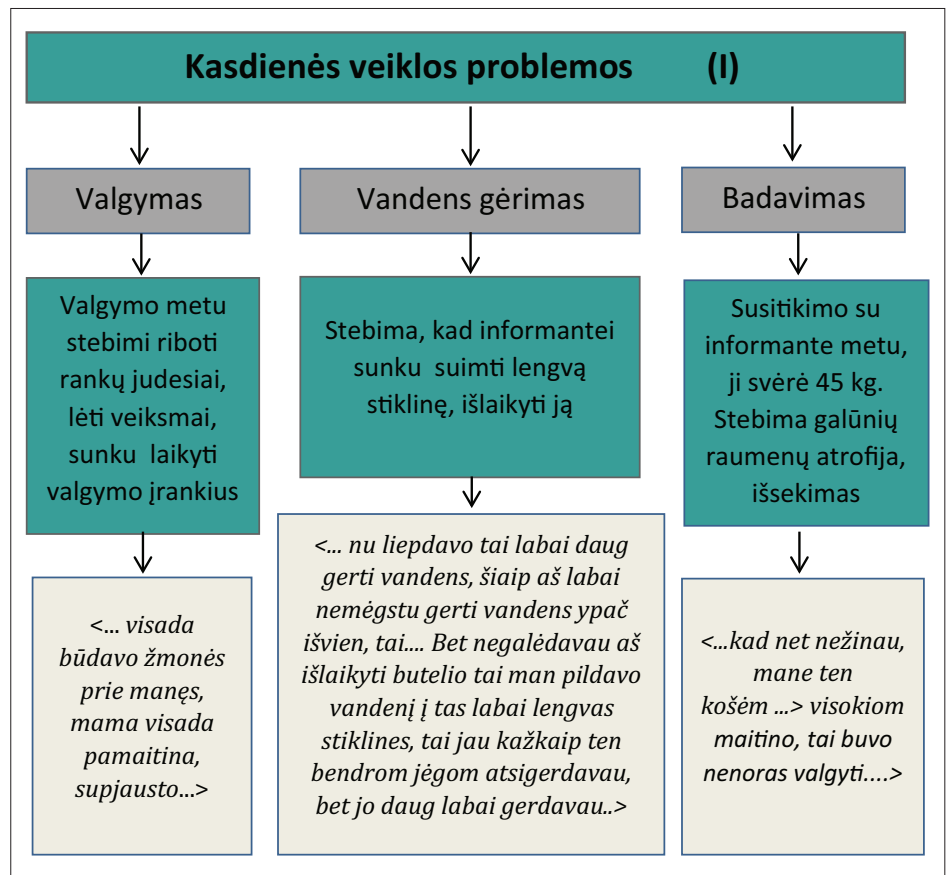

1 pav. Kasdienès veiklos problemos (1)

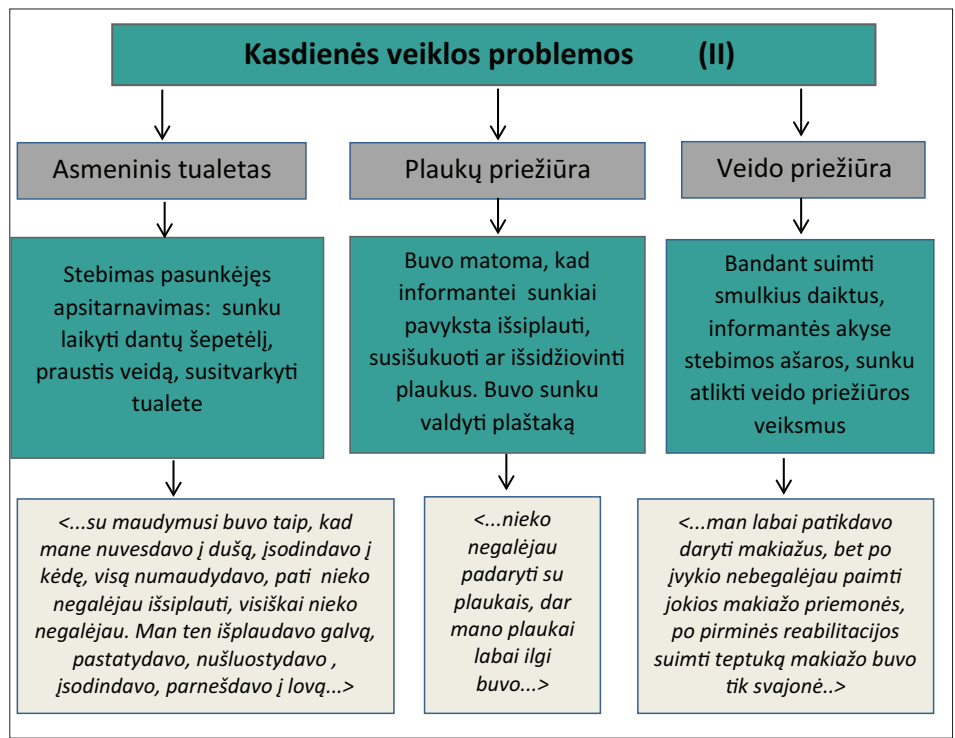

2 pav. Kasdienès veiklos problemos (2) 


\section{Tyrimo rezultatai ir jų aptarimas}

Rankos traumą patyrusių asmenų kasdienės veiklos problemos namuose po reabilitacijos. Pirmoji išanalizuota kategorija buvo atsiradusios kasdienès veiklos problemos. Maisto valgymo ir vandens gérimo ịpročiai turi daug ịtakos asmenims, patyrusiems rankos traumas, jų bendrai būklei, nenorui gerti vandenį ar valgyti, negaléjimui naudotis įrankiais. Svarbu tai, kad nevartojant vandens ar maisto produktų, asmenims po traumų prasidejjus raumenų atrofijai, mažejja

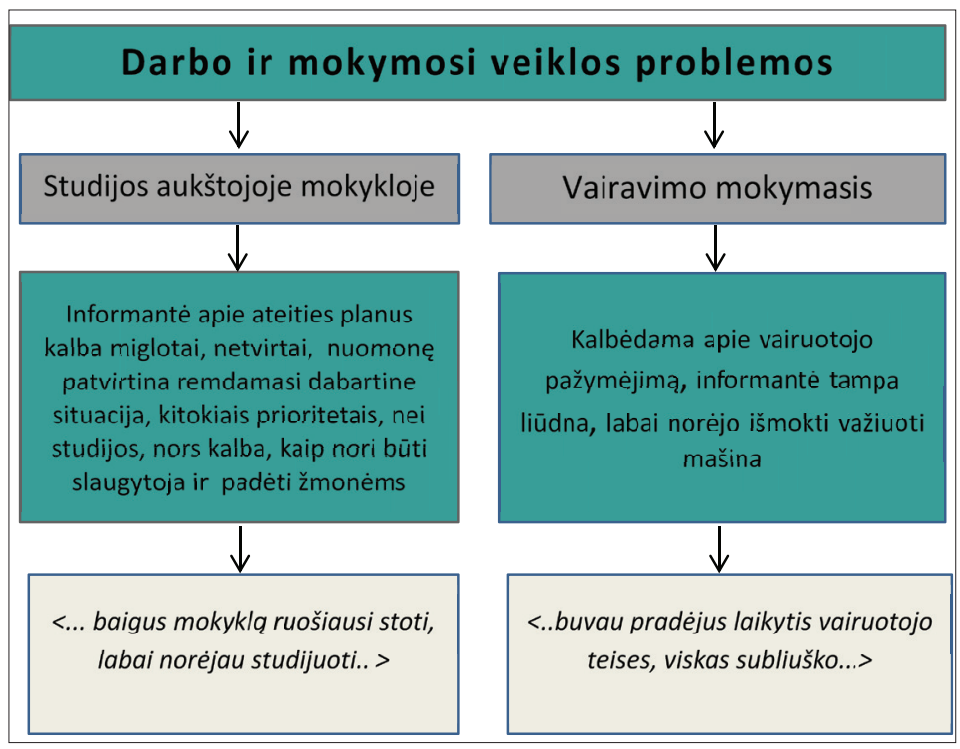

3 pav. Darbo ir mokymosi veiklos problemos

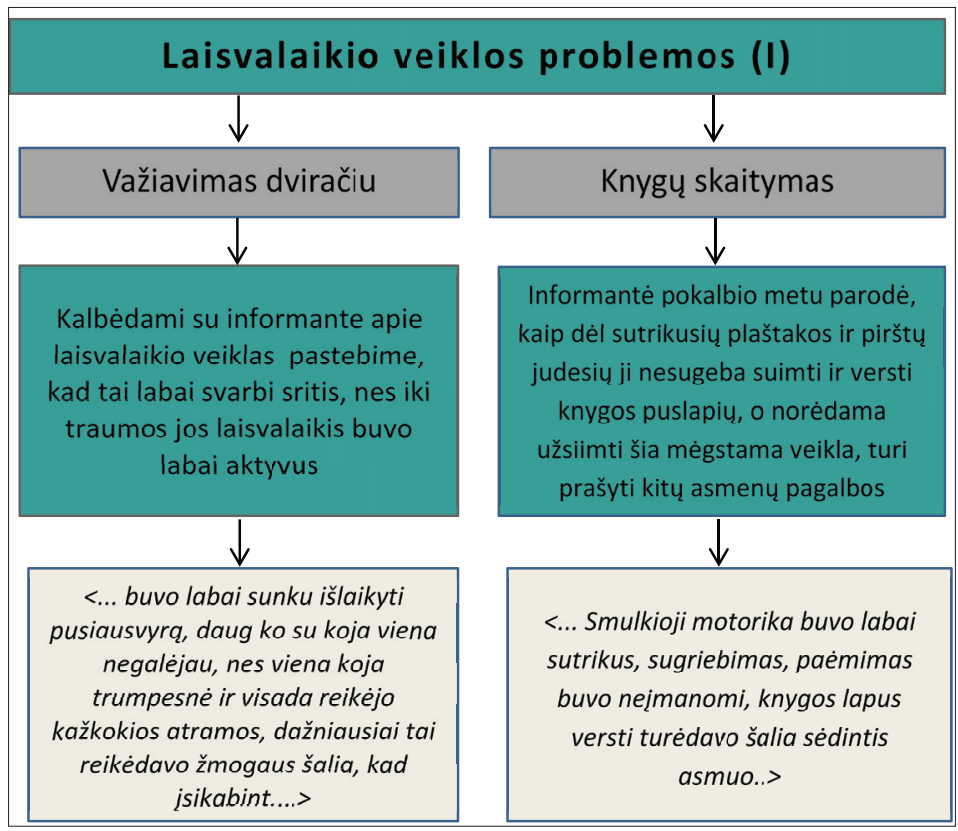

4 pav. Laisvalaikio veiklos problemos (1) ir kūno masè, todèl patartina stebèti svorio kitimą. Ši kategorija buvo suskirstyta ị 3 subkategorijas: valgymas, vandens suvartojimas, badavimas. Jos buvo pagrindžiamos stebėjimu. Traumos liekamieji reiškiniai sukèlè daugybę rūpesčių, o atsiradusios veiklos problemos pablogino gyvenimo kokybę. Stebint informantę valgymo metu, buvo matyti, kad rankų judesiai labai riboti, nerangūs, veiksmai atliekami lètai, sunku laikyti valgymo įrankius, nuolat reikalinga kito asmens pagalba (1 pav.).

Daug buvo savipriežiūros ir namų ruošos problemų. Analizuojant šias veiklas išryškejjo, kad informantè ilgą laiką negalèjo atlikti savipriežiūros, nuolat buvo reikalinga kito asmens pagalba. Paprašius informantès parodyti, kaip suima smulkius daiktus, pastebèta, kad suėmimo veiksmą atlikti sudètinga, o kai nepavykdavo, informante piktai patraukdavo rankas ir sarkastiškai nusijuokdavo (2 pav.).

Dar viena kategorija buvo problemos išeiti iš namų, naudotis transporto priemonėmis bei artimujų palaikymas. Ivykus traumai, informantei tapo sudètinga naudotis viešuoju transportu. Rankos traumas patyrusiems asmenims labai sunku išeiti iš namų, važiuoti, lipti, nes dèl sutrikusios rankų funkcijos kyla problemų, kai tenka lipti ị autobusą, ar ịsitverti jame. Informante teige, kad buvo sunku viską daryti: < ...viena lipti laiptais visiškai negalèjau (nusijuokia). Vaikščioti irgi, visada šalia turèdavo būti žmogus arba kokia atrama, nes eiti buvo labai sunku, šlubuodavau labai. Pas mane visada būdavo žmonès iš šonų, kurie mane laiko, tai aš tokiais mažais žingsniais eidavau, bet nueidavau. Bet labai lètai ir labai sunkiai...> < ...transportas buvo tik privatus, nes negalejjau peržengti staktu, reikdavo, kad būtu su kuo prisisegti, diržai, kad kas duris uždarytų po to išleistų. İsikabinti niekur negalèdavau, tai turedavo būti ị kur įsikabinti galèčiau... > <.. su manim visada būdavo šeimos nariai, draugai ar slaugytojai, kad būčiau viena...> Pasitikejjimo savo jëgomis informantei suteikè artimi žmonès, kurie ja tikejjo ir palaikè. Šių veiklos problemų analizé atskleide, kad dèl patirtos traumos informantè turèjo pakeisti daugeli gyvenimo ipročių.

Rankos traumą patyrusių asmenų darbo ir mokymosi veiklos problemos. Rankos traumą patyrusiems asmenims dažnai tenka sustabdyti ar apriboti darbo ir mokymosi veiklą. Tyrimo metu atsiskleide problemos, susijusios su mokymusi, 
tačiau bendraujant ir stebint informantę, buvo galima suprasti, kad ji nepraranda vilčių ir nori pasveikti, mokytis (3 pav.).

Rankos traumą patyrusių asmenų laisvalaikio veiklos problemos. Kilusios laisvalaikio veiklos problemos skaudino informantę, nes iki patirtos traumos ji buvo veikli, dalyvaujanti ivvairioje veikloje, o po traumos net knygos skaitymas, nesant pagalbininko, buvo neįmanomas, nes negalejo perversti puslapio ir išlaikyti knygos. Stebejjimas atskleide, kad nors kalbèdama informante šypsojosi, ji jautėsi liūdna, kartais akyse buvo pastebimos ašaros (4,5 pav.).

Rankos traumą patyrusių asmenų emocinė būklè. Interviu bei stebèjimo rezultatai parodè, kad informantès emocinè būklè buvo sunki, nuolat kintanti, jai buvo sunku suprasti ir suvokti, kas atsitiko. Buvo sunku susigyventi su įvykusia trauma. Viena jautriausių temų - emocijos. Informantè teigè, kad po traumos ịvyko sunkus psichologinis lūžis. Buvo sunku valdyti emocijas, kamavo neviltis, bejejgiškumas. Vienas iš blogos emocinès būklès simptomų buvo pavargimas, nuovargio jausmas (6 pav.).

Informantės žodžiais, ji mažai judejo, atsirado nuovargio jausmas, buvo sunku atlikti veiksmus, o visa tai lydejjo nenoras nieko daryti. Dar vienas rankos traumas patyrusių asmenų simptomas, paveikiantis ne tik fizinę, bet ir emocinę būklę, nuotaikų kaitą, yra skausmas ir tam tikri raumenų bei bendrieji somatiniai simptomai. Remiantis įvairiais literatūros šaltiniais bei šio tyrimo rezultatais, rankos traumą patyrusiems asmenims psichologiškai būna labai sunku, atsiranda depresija, apatija, po to - susitaikymas. Atliktas tyrimas atskleidè, kad rankų traumą patyrusių asmenų gyvenimo kokybė pasikeičia labai ženkliai. Informantès atsakymuose išryškèjo, kad labai pasikeite jos gyvenimo ịpročiai ir galimybès savarankiškai veikti. Informantei buvo labai sunku, sužinojus apie traumą, pradžioje ji nieko nesuprato ir negalejjo suvokti. Buvo sunku susigyventi su ịvykusia trauma tiek fiziškai, tiek emociškai. Ilinojaus universitete (JAV) atliktas tyrimas, kuriame buvo vertinami asmenys, patyrę rankos traumą arba lūžị, bei kokios gyvenimo sritys nukenčia labiausiai po patirtos traumos. Tyrimo rezultatai buvo panašūs ị šio tyrimo rezultatus, nes tyrimo dalyviams po patirtos traumos sutriko visų gyvenimo sričių veikla - kasdienè, laisvalaikio ir darbinè.
Abiejų tyrimų dalyviams atsirado smulkių daiktų suėmimo problema, sumažèjo griebimo jẻga. Emocinè būklè buvo viena jautriausių temų tiek kalbant su mūsų informante, tiek Ilinojaus universiteto atliktame tyrime. Rankos trauma yra ir psichologinè trauma, nes žmogui tenka susitaikyti su negalia ir savarankiškumo praradimu.

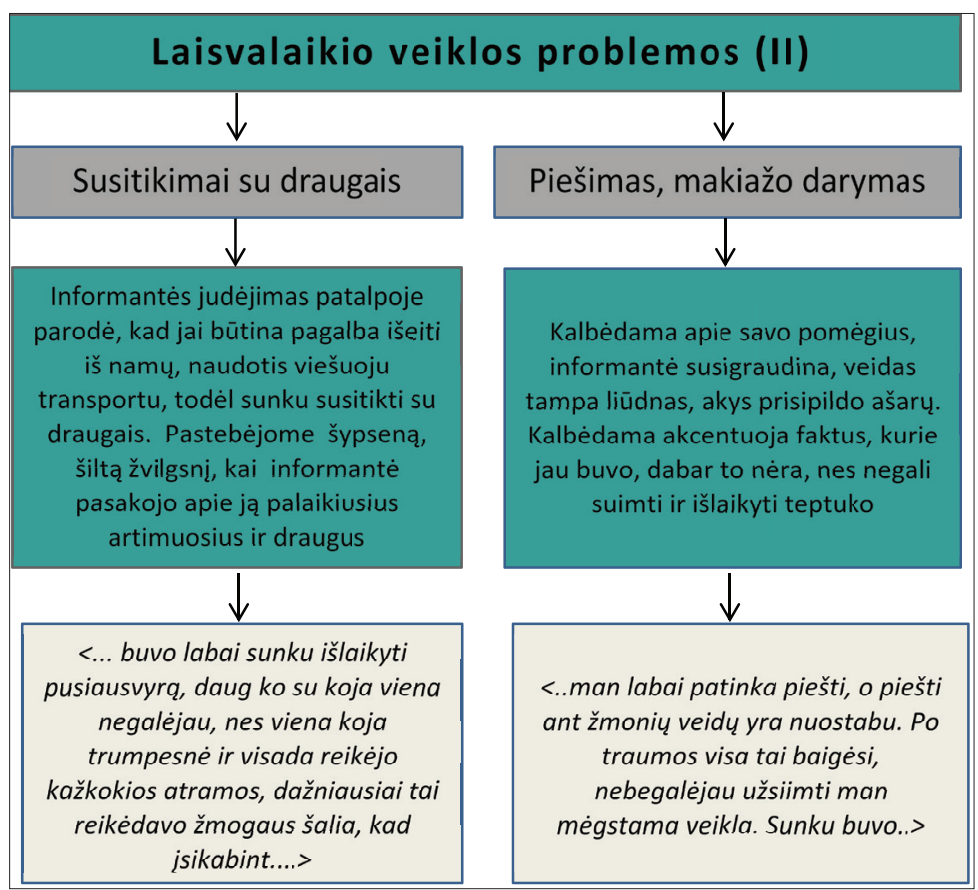

5 pav. Laisvalaikio veiklos problemos (2)

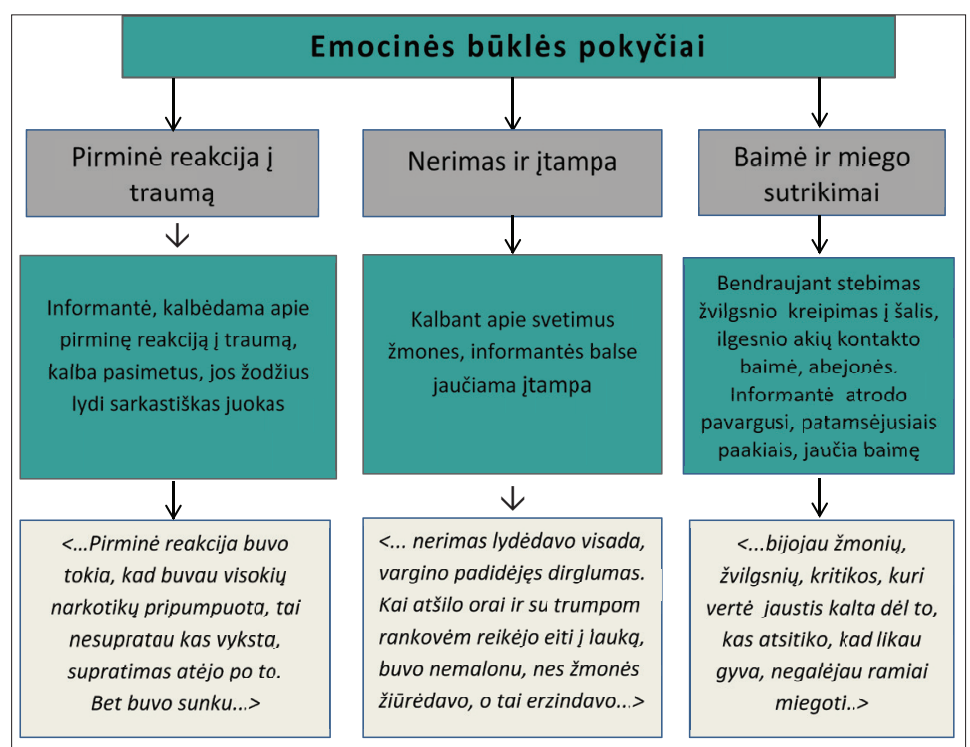

6 pav. Emocinès reakcijos po traumos 


\section{Išvados}

1. Rankos traumą patyrusiam asmeniui sunku prisitaikyti prie veiklos problemų, jis sunkiai priima traumą, sunkiai suvokia, kaip pasikeitè veiklos galimybès. Tai sukelia diskomfortą ir daug klausimų dèl tolesnio gyvenimo. Daugiausia problemų informantei kilo kasdienèje apsirengimo, valgymo, savipriežiūros veikloje.

2. Patirta rankos trauma visiškai sutrikdè informantès darbinę veiklą, nes dèl patirtų sužalojimų ji negalèjo tęsti mokslo ir igyti norimos profesijos, bet labai tikisi, kad pavyks tai igyvendinti.

3. Po patirtos rankos traumos informantè negalèjo užsiimti savo mėgstama laisvalaikio veikla - važiuoti dviračiu, susitikti su draugais, skaityti knygas, piešti, nes buvo nuolat reikalinga kito asmens pagalba: pati negalejo nei perversti knygos puslapio, nei suimti teptuko.

4. Patyrus rankos traumą, emocinè būklè keitèsi nuolat. Pradžioje - depresija, nes teko išgyventi draugų netektị ir pripažinti savo negalią, po to - pyktis, kodèl taip nutiko, tada apatija ir nenoras nieko daryti. Po atlikto stebejjimo galime teigti, kad informante yra susitaikiusi su esama situacija ir stengiasi būti kuo labiau nepriklausoma nuo kitų.

\section{Literatūra}

1. Braddom R, Saunders AL. Physical medicine and rehabilitation 4th ed. Section 4. Issues and specific diagnosis. 2011.

2. Braziulis K. Rankos biomechaninès funkcijos ịvertinimas gydant stipinkaulio distalinès dalies lūžius delnine rakinama plokštele: daktaro disertacija. LSMU, 2014;103.

3. Brotzman SB, Wilk KE. Clinical orthopaedic rehabilitation 2003; Philadelphia: Mosby.

4. Bucevič D. Ergoterapijos ir veidrodžio terapijos poveikis asmenų, patyrusių stipinkaulio tolimojo galo lūžị, savarankiškumui ir rankos funkcijai. Magistro baigiamasis darbas. LSMU, 2020.

5. Clark GL, Wilgis EF et al. Hand rehabilitation: a practical guide. 2007.

6. Karunadasa K. Management of the injured hand - basic principles of care. Sri Lanka Journal of Surgery 2015;33(1). https://doi.org/10.4038/sljs.v33i1.8123

7. Kriščiūnas A. ir kt. Reabilitacijos pagrindai. Kaunas: Vitae Litera, 2008.

8. Lee JS, Kim YH. Factors associated with limited hand motion after hand trauma. Medicine (Baltimore) 2019;98(3). https://doi.org/10.1097/MD.0000000000014183
9. Jones LA, Lederman SJ. Human hand function. Oxford University Press 2006.

https://doi.org/10.1093/acprof:oso/9780195173154.001.0001

10. Prosser R, Conolly WB. Rehabilitation of the hand and upper limb. 2003.

\section{EMOTIONAL STATE AND ACTIVITY ISSUES AT HOME AFTER REHABILITATION OF PEOPLE WITH ARM INJURIES}

M. Gintilienè, A. Pranskaitytè-Bielevičienė, B. Dūdaitė

Keywords: occupational therapy, hand function, hand anatomy, hand injuries, rehabilitation.

Summary

Hand injuries have been and continue to be very relevant at all times, as daily actions are performed by hand, and structures important to function can be injured during injuries. This results in the restriction of hand movements, which negatively affects the performance of daily activities and disrupts different aspects of human life [4]. People who have often suffered trauma close at home, and such social passivity has a significant impact on a person's life, opportunities and position in society, and determines social relationships [3]. The aim of the research was to reveal the activity problems and emotional state of persons who experienced hand injury at home after rehabilitation, to find out what problems a person suffering from hand injury has during daily activities, how the person's work activity changed, how the hand injury affected the person's leisure time and what were changes in a person's emotional state after trauma. The study involved a person after a car accident who suffered multiple fractures of both bones. Observations were used for data collection, according to the observation protocol developed by the authors of the work, and semi-structured interviews with pre-prepared key open-ended questions. The content analysis of the obtained data was performed. The analysis of the obtained data showed that it is difficult for people with hand injury to adapt to performance problems, which causes discomfort, disrupts daily activities, mostly problems in dressing, eating and self-care activities. The hand injury suffered disrupts work activities, because due to the injuries suffered, the informant could no longer continue his studies and acquire the desired profession, and could no longer engage in his favorite leisure activities. The emotional state of the person who suffered the hand injury was constantly changing, but during the study, the informant was reconciled to the current situation and tried to be as independent of others as possible.

Correspondence to: aiste.pranskaityte@go.kauko.lt

Gauta 2021-11-14 